\title{
Academic Procrastination: Associations with Personal, School, and Family Variables
}

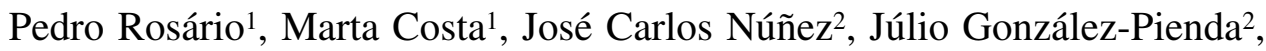 \\ Paula Solano ${ }^{2}$, and Antonio Valle ${ }^{3}$ \\ ${ }^{1}$ Universidade do Minho (Portugal) \\ ${ }^{2}$ Universidad de Oviedo (Spain) \\ ${ }^{3}$ Universidad de A Coruña (Spain)
}

Procrastination is a common behavior, mainly in school settings. Only a few studies have analyzed the associations of academic procrastination with students' personal and family variables. In the present work, we analyzed the impact of socio-personal variables (e.g., parents' education, number of siblings, school grade level, and underachievement) on students' academic procrastination profiles. Two independent samples of 580 and 809 seventh to ninth graders, students attending the last three years of Portuguese Compulsory Education, have been taken. The findings, similar in both studies, reveal that procrastination decreases when the parents' education is higher, but it increases along with the number of siblings, the grade level, and the underachievement. The results are discussed in view of the findings of previous research. The implications for educational practice are also analyzed.

Keywords: academic procrastination, socio-family variables, adolescents

La procrastinación es un comportamiento muy frecuente, sobretodo entre la población escolar. Pocos estudios han analizado las relaciones entre la procrastinación académica y variables personales y familiares. En este trabajo analizamos el impacto de variables socio-personales tales como la escolaridad de la madre y del padre, el número de hermanos, el curso y el fracaso escolar evaluado a través del número de cursos suspensos utilizando ANOVAS en dos muestras independientes de 580 y 809 sujetos de los 3 primeros cursos de Enseñanza Secundaria Obligatoria (ESO). Los datos, similares en los dos estudios, revelan que la procrastinación decrece con el aumento de escolaridad de la madre y del padre, pero incrementa con el número de hermanos, el curso en ESO y el fracaso escolar. Los resultados son discutidos en función de los hallazgos de las investigaciones previas. Se analizan las implicaciones para la práctica educativa.

Palabras clave: procrastinación académica, variables socio-familiares, adolescentes

This work was funded by a research scholarship from the Fundação para a Ciência e a Tecnologia, Portugal (PTDC/CED/66503/2006).

Correspondence concerning this article should be addressed to: Pedro Rosario. Universidade do Minho, Departamento de Psicología, Campus de Gualtar, P-4710 Braga (Portugal). E-mail: prosario@iep.uminho.p

How to cite the authors of this article: Rosario, P., Costa, M., Núñez, J.C., González-Pienda, J., Solano, P., Valle, A. 
The term procrastinate comes from the Latin word procrastinare and means to put off, delay, prolong, defer, stall, or postpone performing a task. Procrastinating implies performing an alternative activity to the one intended, which is not synonymous with idleness (Schouwenburg, 2004). Procrastination can even be distinguished from the intentional postponement of a task-because procrastination is unplanned-or from logical and necessary delay, due to understandable reasons such as illness or technical problems (Burka \& Yuen, 1983; Milgram, Sroloff, \& Rosenbaum, 1988; van Eerde, 2003). Procrastination can be temporary or permanent and can be defined as a function of the behavioral output - putting off the action-or the cognitive outputputting off making a decision (Dewitte \& Lens, 2000).

Procrastination is a common behavior in contemporary societies (Ferrari, Johnson, \& McCown, 1995; Ferrari, O'Callaghan, \& Newbegin, 2005). For example, almost $20 \%$ of the adults admit they procrastinate when faced with routine tasks such as paying bills, paying taxes, or undergoing medical examinations (Schouwenburg, 2004). According to McCown and Johnson (1989), for about 25\% of the non-student adult population, procrastination is usually a big problem, and in $40 \%$ of the cases it had caused significant financial loss. These data have been replicated by more recent investigations (e.g., Dewitte \& Schouwenburg, 2002), which allows us to state that procrastination is a recurrent behavior in modern societies.

Despite the fact that procrastination occurs in all kinds of daily tasks (Alexander \& Onwuegbuzie, 2007), academic procrastination is highly frequent in students and regarded as detrimental to academic progress and success justifying thus its study. Adolescents spend a lot of their time either at school or involved in school activities, and the school setting is characterized by "limited times" in which to perform tasks, investigation work, and exams (Rosário et al., in press). It is estimated that academic procrastination in tasks related to academic life is a common phenomenon for about $70 \%$ of university students (Ferrari et al., 2005). In an investigation with adolescents, almost $25 \%$ of the individuals interviewed considered that procrastination was a moderate or severe problem (Aitken, 1982) and that the tendency to put off tasks interfered negatively not only with their academic achievement but also with their quality of life (Moon \& Illingworth, 2005). The most frequent consequence of procrastination is poor individual performance which interferes with organizational functioning (Dewitte \& Schouwenburg, 2002).

Several studies associate procrastination with some different personality variables, such as low self-esteem, low self-confidence, high perfectionism, competitive immobilism, dysfunctional impulsivity, depression, and anxiety (Ferrari \& Díaz-Morales, 2007; Ferrari \& Emmons, 1995; Flett, Hewitt, \& Martin, 1995; van Eerde, 2003). In general, procrastination can be considered to interfere with people's will and their engagement in tasks, resulting in the increase of stress reactions, characterized by negative feelings, loss of control over their personal lives, or consequences for their physical and mental health (Delongis, Coyne, Dakof, Folkman, \& Lazarus, 1982; Senécal, Koestner, \& Vallerand, 1995; Tice \& Baumeister, 1997). According to literature procrastination is associated with a maladaptive life style, resulting in serious personal and social effects which reinforce feelings of lack of personal competence (Brownlow \& Reasinger, 2000; Burka \& Yuen, 1983; Ferrari et al., 1995); beside this it is known that the prolonged exposure to stress can increase the risk of serious illness. Obviously, when it turns to our students' lives, procrastination can also cause delay in studying behaviors (Rothblum, Solomon, \& Murakami, 1986; Tice \& Baumeister, 1997), in drafting works or reports, missing deadlines to hand in papers, and putting off administrative tasks related to academic life, such as returning library books, registering for an exam, and so forth. (Scher \& Ferrari, 2000; Rothblum et al., 1986). Skipping classes or delaying in handing in works are also consequences of academic procrastination (Scher \& Osterman, 2002), as well as emerging conflicts with parents or friends (Ferrari, Harriott, \& Zimmerman, 1999).

Despite the fact that the consequences of procrastination have already been explored in some depth, the analysis of its causes has been as yet scarcely investigated. One of the lines of current research within the field of motivational variables in adolescence has analyzed the relation among self-regulated learning processes, variables in adolescents' lives, and procrastination. An important number of researchers have described procrastination as a failure in self-regulation processes (Blunt \& Pylchyl, 2005; Dewitte \& Lens, 2000; Vohs \& Baumeister, 2004; Wolters, 2003). However, the relations among these variables are still not completely clear (Schouwenburg, 2004).

Another line of research that is being currently developed relates to the family role in this process. Family undoubtedly plays an essential role in the acquisition of suitable habits (Rosário, Mourão, Núñez, González-Pienda, \& Solano, 2006). Burka and Yuen (1983), for example, suggested that procrastinators push themselves excessively, and that behavior usually occurs in demanding families that doubt on the child's ability to be successful. Parental expectations and high levels of criticism are usually associated with a kind of socially prescribed perfectionism that is positively correlated to procrastination (Ferrari \& Díaz-Morales, 2007; Pylchyl, Coplan, \& Reide, 2002). Ferrari and Olivetti (1993, 1994) and Scher and Ferrari (2000) suggest that family dynamics plays an important, albeit indirect, role in procrastination.

Onwuegbuzie (2000) concluded that academic procrastination should be considered "from a broad social perspective" (p.108), and van Eerde (2003) stressed the importance of analyzing the social influences on students' academic procrastination in his meta-analysis on the same subject. In this sense, the goal of our work is to analyze 
the impact of some socio-personal variables on academic procrastination behavior, once the role of family and educational variables in procrastination behaviors is still unclear. In other words, our present work has been carried out in order to examine the profile of association of some family and educational variables with academic procrastination.

\section{Study 1}

\section{Method}

\section{Participants}

This study enrolled 580 students $(47.8 \%$ males and $52.2 \%$ females). Their ages ranged between 11 and 17 years $(M=13.50, S D=1.12)$.

Academic variables. Concerning grade level, they were students from seventh- to ninth-grades Portuguese Compulsory Education, and were distributed evenly among the three school year grades: $31 \%\left(7^{\text {th }}\right), 31.2 \%\left(8^{\text {th }}\right)$, and $37.8 \%\left(9^{\text {th }}\right)$, respectively. Concerning academic underachievement (assessed by the number of school years failed), we found that a significant number of youths had never failed $(81.7 \%)$, and that $12.6 \%$ had failed once, $5 \%$ twice, and $0.7 \%$ had failed three or more times.

Family variables. Regarding parents' education, $12.2 \%$ of the mothers and $15 \%$ of the fathers had not completed primary education $\left(4^{\text {th }}\right.$ grade), $30.7 \%$ of the mothers and $29 \%$ of the fathers had finished compulsory education $\left(9^{\text {th }}\right.$ grade), and $26.6 \%$ (mothers) and $16.6 \%$ (fathers) had completed Portuguese secondary school $\left(12^{\text {th }}\right.$ grade). About one fourth of the mothers (26.6\%) and of the fathers (25.2\%) had completed a university degree, and only $4 \%$ of the mothers and 5\% of the fathers had carried out post-graduate studies. With regard to the number of siblings, $18.4 \%$ of the adolescents were an only child, $56.4 \%$ had one sibling, $18.4 \%$ two siblings, $4.8 \%$ three siblings, and $1.9 \%$ had four or more siblings.

\section{Materials}

Procrastination. This variable was assessed by the Cuestionario de Procrastinación en el Estudio (CPE; Rosário et al., in press), a 10-item instrument, with 5 items belonging to the Daily Study Procrastination subscale (e.g., "I am upto-date in my studies because I work every day." "When I have important school work to do, I start as soon as possible", $\alpha=.73$ ), and 5 items belonging to the Studying for Exams Procrastination subscale (e.g., "When I study for exams, I'm often absent minded;" "I interrupt studying to do other things-for instance, watch TV, listen to music, or talk on the mobile...;" $\alpha=.75)$. Participants responded on a 5-point Likert-type scale, ranging from 1 (never) to 5 (always). The instrument presents a fairly robust alpha coefficient: $\alpha=.81$.

\section{Procedure}

The questionnaires were administered in five public schools in Northern Portugal. The adolescents' participation was voluntary and the parents had given their written consent. As the goal of this investigation was to determine the possible existence of associations among the personal, academic, and family variables and procrastination, we used one-factor analysis of variance (ANOVA) to analyze the data. As each variable had more than two levels or groups, in order to determine whether there were or weren't significant mean differences, we used Scheffe's post hoc contrasts.

\section{Results}

\section{Initial Analysis of the Correlations}

In Table 1 are presented the descriptive data and the correlations between the variables in study.

The results displayed in this table show that, on the one hand, procrastination decreases as the parents' educational level increases, but, on the other hand, it increases along

Table 1

Means, Standard Deviations and Correlations of the First Sample $(n=580)$

\begin{tabular}{lrrrrrrr}
\hline Variables & $M$ & $S D$ & 1 & 2 & 3 & 4 & 5 \\
\hline 1. Procrastination & 24.50 & 5.90 & & & & & \\
2. Mothers' education & 2.77 & 1.12 & $-.176^{* *}$ & & & & \\
3. Fathers' education & 2.73 & 1.18 & $-.156^{* *}$ & $.799^{* *}$ & & & \\
4. Number of siblings & 1.20 & 1.18 & $.104^{*}$ & -.029 & .000 & & \\
5. School grade level & 8.06 & 0.83 & $.246^{* *}$ & $-.145^{* *}$ & $-.144^{* *}$ & .011 & \\
6. Underachievement (number of school years failed) & 0.24 & 0.57 & $.179^{* *}$ & $-.341^{* *}$ & $-.294^{* *}$ & .061 & $.112^{* *}$ \\
\hline
\end{tabular}

${ }^{*} p<.05 .{ }^{* *} p<.01 .{ }^{* * *} p<.001$. 
with the number of siblings, the grade level, and the underachievement. The mothers' and fathers' educational levels were strongly intercorrelated and, although neither one was related to the number of siblings, they were both significantly and negatively related to their children's underachievement and grade level. These two variables were also positively and significantly related, indicating that the higher the school year grade level, the higher the underachievement. With regard to procrastination, the more educated the parents were the less procrastination their children displayed. In contrast, the more siblings, the higher the students' school grade level and underachievement, the more procrastination was displayed by them.

\section{Analysis of Mean Differences}

In Table 2 are presented the descriptive data of the various levels of family variables.

The results indicate that the differences observed in academic procrastination, as a consequence of the effect of the different levels of the variables, were statistically significant in all five cases: mothers' education, $F(4,575)=$ 4.45, $p<.001, \eta^{2}=.03$; fathers' schooling, $F(4,521)=3.76$, $p<.05, \eta^{2}=.028$; number of siblings, $F(4,575)=2.74, p$ $<.05, \eta^{2}=.019$; grade level, $F(2,577)=19.18, p<.001$, $\eta^{2}=.062$; and underachievement, $F(3,576)=6.88, p<.001$, $\eta^{2}=.035$. However, although all the differences were statistically significant, their effect size was very small (even in the cases in which the statistical significance level of the differences was $p<.001$ ).

The results derived from the analysis of the differences of the various levels of the independent variables show that these differences were not statistically significant at all the levels. Thus, for the variable mothers' education, we obtained statistically significant differences between the groups of primary school-university graduates and secondary schooluniversity graduates $\left(M D_{\text {Primary school-U. graduates }}=2.60, p<\right.$ $\left..05 ; M D_{\text {Secondary-U. graduates }}=2.19, p<.05\right)$, but not among the rest of the levels of this variable. Regarding the variable fathers' education, the data revealed statistically significant differences only between the groups secondary-university graduates $\left(M D_{\text {Secondary-U. graduates }}=2.16, p<.05\right)$. In the

Table 2

Means and Standard Deviations of the Predictor Variables of Academic Procrastination in the First Sample $(n=580)$

Socio-Family Variables

Procrastination

\begin{tabular}{|c|c|c|}
\hline & $M$ & $S D$ \\
\hline \multicolumn{3}{|l|}{ Mothers' education } \\
\hline Primary & 25.74 & 5.30 \\
\hline Secondary & 25.33 & 6.14 \\
\hline High school & 24.60 & 5.22 \\
\hline University degree & 23.14 & 6.27 \\
\hline Post-graduate & 22.56 & 5.69 \\
\hline \multicolumn{3}{|l|}{ Fathers' education } \\
\hline Primary & 25.24 & 4.97 \\
\hline Secondary & 25.15 & 6.54 \\
\hline High school & 24.52 & 4.95 \\
\hline University degree & 22.99 & 5.89 \\
\hline Post-graduate & 22.96 & 5.44 \\
\hline \multicolumn{3}{|l|}{ Number of siblings } \\
\hline One & 24.23 & 5.99 \\
\hline Two & 24.02 & 5.86 \\
\hline Three & 25.33 & 6.10 \\
\hline Four or more & 27.21 & 4.80 \\
\hline \multicolumn{3}{|l|}{ School grade level } \\
\hline Seventh grade & 22.44 & 6.18 \\
\hline Eighth grade & 24.74 & 5.66 \\
\hline Ninth grade & 25.99 & 5.36 \\
\hline \multicolumn{3}{|c|}{ Underachievement (number of school years failed) } \\
\hline None & 23.98 & 5.92 \\
\hline One & 26.47 & 5.43 \\
\hline Two & 27.48 & 4.93 \\
\hline Three & 27.25 & 5.56 \\
\hline
\end{tabular}


variable number of siblings, despite the fact that statistically significant differences were obtained at the global level, the particular differences among the levels of this variable did not reach significance. For the variable grade level, Scheffé's test revealed statistically significant differences between the groups of $7^{\text {th }}$ and $8^{\text {th }}$ graders and $7^{\text {th }}$ and $9^{\text {th }}$ graders $\left(M D_{7 \text { th }}\right.$ -8 th $=-2.29, p<.001$ and $M D_{7 \text { th }-9 \text { th }}=3.54, p<.001$, respectively). Lastly, the data for the variable academic underachievement, measured as the number of school years failed, revealed statistically significant differences between levels none-one and none-two $\left(M D_{\text {none-one }}=-2.49, p<.01\right.$ and $M D_{\text {none-two }}=-3.49, p<.05$, respectively).

\section{Discussion}

The results of this first study suggest that within this range of school years (middle school) the levels of procrastination displayed by students tend to increase with the grade level. Although these data could not be compared with other than the ones in the Portuguese literature (e.g., Costa, 2007; Rosário et al., 2005; Rosário et al., 2006), they are somehow in line with those of Van Eerde (2003) concerning students above 16 years old, once he stated that age was negatively associated with procrastination. In accordance with the findings of a study using a sample of more than 4,000 Portuguese students from fifth to ninth grades which indicate that self-regulated learning decreases as students' age and grade level grows (Rosário, Soares, Núñez, González-Pienda, \& Rubio, 2004; Rosário et al., 2006), our results could be explained not only by the effect of the students' growing familiarity with the educational environments and contexts, but also by the low academic demandings students perceive in those same environments by the time they are finishing compulsory education. Thus, once the youths have become accustomed to the teaching system and are more familiar with the school setting, their level of adjustment and commitment to school tasks decreases instead of increasing (Rosário et al., 2004; Rosário et al., 2007).

In the present study, the levels of academic procrastination increased as the students advanced throughout their educational process, and consequently did the underachievement. Albeit indirectly, these data indicate that adolescents usually put off difficult and unpleasant tasks that involve high doses of effort and may then generate anxiety (Blunt \& Pylchyl, 2005; Ferrari \& Scher, 2002), preferring to engage in activities that are more interesting to them (Ferrari, Harriott, Evans, Lecik-Michna, \& Wenger, 1997). Their perception of task difficulty may be a significant factor that contributes to increasing procrastination behaviors.

As far as fathers' and mothers' education is concerned, these variables present an inversely proportional association with academic procrastination, that is, when they increase, procrastination tends to decrease. More educated parents, usually occupying professional posts of higher social relevance, value more their children's studies and learning, as they consider them important tools for their children's future academic and social success. Therefore, they try to inculcate this working ethics in their children. Youths immersed in demanding socio-educational settings usually perceive and internalize the importance their parents attribute to academic success, and this way tend to adopt behaviors coherent with this perception (Scher \& Ferrari, 2000). Parents' higher instructional levels may even be associated with more support or better quality support while their children are studying for exams and during their daily study periods, likely preventing academic procrastination. Epstein (2001) maintains this hypothesis, suggesting that parents with higher educational levels are generally more involved in their children's school life and education as they feel better prepared to do it and because they have higher future expectations for their children's. Furthermore, mothers' higher instructional levels may be associated with higher levels of self-regulation, and this competence may be transferred to children by social modeling, teaching, and direct feedback, increasing their commitment to school work and thus preventing academic procrastination (Rosário et al., 2006). Grolnick and Ryan (1989) suggest that parents who stimulate their children's autonomy and who provide more task structure and monitoring are more likely to promote their children's selfregulation.

In this first study, academic procrastination also increased as a function of the number of siblings. This variable isn't usually taken into account by research, but, as indicated by the data of this study, it contributes, although modestly, to better understand academic procrastination. The increase of the number of siblings associated with greater tendency towards procrastination could be due to the fact that these youths are facing distracting and more appealing non-academic tasks than that of studying, acting their brothers or sisters either as distracters interrupting insistently their study time or playing as role models of academic low-commitment. The fact that procrastination is positively related to school grade level (in close connection with age) also suggests that the older siblings may be modeling their younger siblings' procrastination behaviors.

A higher number of siblings is usually associated with more noise and distractions, but also with parents lack of time to support their children's performance of school work, homework, and personal study. As age differences become more pronounced, the siblings' interests and free time activities do not coincide and this could hinder some of the siblings' concentration on academic tasks.

Although the results in this first study seem to be consistent with literature, due to the small size effect found, future research with other different samples is needed in order to confirm not only the same kind of profiles of 
associations but also to measure their strength. That's the reason why we have replicated the first study in a second one using another equivalent sample.

In this second study, we attempted to contrast the reliability of the results obtained in the first study. In this sense, the two studies are similar, both in the methodological procedure and in the materials used; the difference between them is that they used independent samples. In this section, we will therefore only provide information about the academic and family characteristics of the participants in the sample.

\section{Study 2 \\ Method}

\section{Participants}

In this study, 809 students $(48.6 \%$ males and $51.4 \%$ females) were participants, with ages between 11 and 17 years $(M=13.48, S D=1.12)$.

Academic variables. As with the students in the first study, these students of middle school were enrolled in the same school grade levels ( $7^{\text {th }}$ to $9^{\text {th }}$ ), and were also distributed evenly among the three school year grades: $31.8 \%$ $\left(7^{\text {th }}\right), 32 \%\left(8^{\text {th }}\right)$, and $36.2 \%\left(9^{\text {th }}\right)$. In connection with underachievement an important number of youths had never failed $(82.7 \%)$, and $11.2 \%$ had failed once, $5.2 \%$ twice, and $1 \%$ failed three or more years.

Family variables. Regarding parents' education, 12.6\% of the mothers and $14.5 \%$ of the fathers had only completed Primary Education; $30.3 \%$ of the mothers and $28.8 \%$ of the fathers had completed Compulsory Education ( $9^{\text {th }}$ grade); and $20.1 \%$ of the mothers and $18.3 \%$ of the fathers had completed the full Secondary Education cycle (12 $2^{\text {th }}$ grade); lastly, $25.5 \%$ of the mothers and $24.6 \%$ of the fathers had a university degree or diploma; and only $3.7 \%$ of the mothers and $4.7 \%$ of the fathers had post-graduate studies. With regard to the number of siblings, $19.3 \%$ of the adolescents were an only child, $56 \%$ had one sibling, $18 \%$ two, 5\% three, and $1.7 \%$ four or more siblings.

\section{Results}

In Table 3 are displayed the descriptive data of the variables included in the study and their intercorrelations.

The data provided in this table are very similar to those in Table 1, corresponding to the sample of the first study. Specifically: (a) procrastination decreases when the students' parents have higher instructional levels and increases along with the increase in the number of siblings, the grade level, and academic underachievement; (b) mothers' and fathers' educational levels are strongly correlated, but neither one of them is related to the number of siblings, whereas they are negatively related to their children's grade level and academic underachievement; and (c) the grade level and the academic underachievement are positively and significantly related.

As can be seen in Table 4, the results obtained in the ANOVA, as with the correlations, coincide with those obtained in the first study (see Table 2). The contrast of the mean differences indicates that all five variables predict a significant part of the variability of procrastination: mothers' schooling, $F(4,804)=5.55, p<.001, \eta^{2}=.027$; fathers' schooling, $F(4,730)=3.67, p<.01, \eta^{2}=.020$; number of siblings, $F(4,804)=4.22, p<.01, \eta^{2}=.021$; school grade level, $F(2,806)=17.69, p<.001, \eta^{2}=.042$; and academic underachievement, $F(3,805)=11.63, p<$ $.001, \eta^{2}=.042$. However, as with the first study, the effect size was very small.

From the comparison of the means of the specific levels within each variable with Scheffé's test, the results of the first study are generally repeated in the second one: (a) in the variable mothers' education, mean differences were obtained between the Primary and university degree groups $\left(M D_{\text {Primary-U. degree }}=2.41, p<.05\right)$, and between the secondary and the university degree groups $\left(M D_{\mathrm{SCE} . \mathrm{U} \text {. degree }}\right.$ $=2.08, p<.05)$, but not in the remaining possible comparisons; (b) for the fathers' education, no differences were found in any of the levels of the variable; (c) in the variable number of siblings, differences were obtained between the levels none and three siblings $\left(M D_{\text {none-three }}=\right.$ $-3.75, p<.05)$ and one and three siblings $\left(M D_{\text {one-three }}=\right.$ $-3.64, p<.05$ ); (d) for the variable school grade level, statistically significant differences were obtained between

Table 3

Means, Standard Deviations and Correlations of the Second Sample $(n=809)$

\begin{tabular}{|c|c|c|c|c|c|c|c|}
\hline Variables & $M$ & $S D$ & 1 & 2 & 3 & 4 & 5 \\
\hline 1. Procrastination & 24.61 & 5.96 & & & & & \\
\hline 2. Mothers' education & 2.77 & 1.12 & $-.169 * *$ & & & & \\
\hline 3. Fathers' education & 2.73 & 1.18 & $-.138 * *$ & $.789 * *$ & & & \\
\hline 4. Number of siblings & 1.20 & 1.18 & $.116^{* *}$ & .014 & .008 & & \\
\hline 5. School grade level & 8.06 & 0.83 & $.202 * *$ & $-.107 * *$ & $-.105 * *$ & -.041 & \\
\hline 6. Underachievement (number of school years failed) & 0.24 & 0.57 & $.196^{* *}$ & $-.334 * *$ & $-.286^{* *}$ & $.115^{* *}$ & $.072 *$ \\
\hline
\end{tabular}

$* p<.05 . * * p<.01 . * * * p<.001$. 
Table 4

Means and Standard Deviations of the Predictor Variables of Academic Procrastination in the Second Sample $(n=809)$

\begin{tabular}{|c|c|c|}
\hline \multirow{2}{*}{ Socio-Family Variables } & \multicolumn{2}{|c|}{ Procrastination } \\
\hline & $M$ & $S D$ \\
\hline \multicolumn{3}{|l|}{ Mothers' education } \\
\hline Primary & 25.80 & 5.69 \\
\hline Secondary & 25.47 & 6.11 \\
\hline High school & 24.56 & 5.53 \\
\hline University degree & 23.39 & 6.18 \\
\hline Post-graduate & 22.46 & 5.29 \\
\hline \multicolumn{3}{|l|}{ Fathers' education } \\
\hline Primary & 25.52 & 5.23 \\
\hline Secondary & 25.09 & 6.60 \\
\hline High school & 24.54 & 5.32 \\
\hline University degree & 23.61 & 5.92 \\
\hline Post-graduate & 22.52 & 4.97 \\
\hline \multicolumn{3}{|l|}{ Number of siblings } \\
\hline One & 24.14 & 5.96 \\
\hline Two & 24.26 & 5.90 \\
\hline Three & 25.22 & 6.00 \\
\hline Four or more & 27.90 & 5.92 \\
\hline \multicolumn{3}{|l|}{ School grade level } \\
\hline Seventh grade & 22.93 & 6.32 \\
\hline Eighth grade & 24.87 & 5.81 \\
\hline Ninth grade & 25.87 & 5.41 \\
\hline \multicolumn{3}{|c|}{ Underachievement (number of school years failed) } \\
\hline None & 24.07 & 5.93 \\
\hline One & 26.93 & 5.46 \\
\hline Two & 27.42 & 4.73 \\
\hline Three & 29.61 & 5.96 \\
\hline
\end{tabular}

the students of seventh and eighth grade $\left(M D_{7 \text { th }-8 \text { th }}=-1.93\right.$, $p<.05)$ and between seventh and ninth graders $\left(M D_{7 \text { th-9th }}\right.$ $=-2.93, p<.05$ ), but not between eighth and ninth graders, indicating that seventh grade students comply more with the school demands and put off their tasks less, but their involvement decreases as they advance in schooling; and lastly, (e) regarding the variable academic underachievement, the data show statistically significant differences between none and one year failed $\left(M D_{\text {none-one }}=-2.86, p<.001\right)$ and between none and two years failed $\left(M D_{\text {none-two }}=-3.35, \mathrm{p}\right.$ $<.05$ ), but not between the rest of the possible comparisons.

\section{Discussion}

As previously mentioned, the results of this second study have generally confirmed those obtained in the first study. Thus, the levels of academic procrastination increase with the grade level, a fact that needs to be supported by further research once we've not found other data concerning middle school, but as we've reported, studies at college level stress that procrastination is more likely to be found in younger ages (van Eerde, 2003). As in Study 1, parents' education is significantly associated with procrastination, in the sense that the higher the parents' level of education, the less academic procrastination behavior their children display. An interesting fact that emerged in this second study, and that we had already found in the first one, is that the number of siblings is positively and significantly related to academic procrastination (the more siblings, the more procrastination). Given that this fact appears in the two studies for the first time, it would be interesting for future research to analyze how these two variables are related in order to intervene when the level of academic procrastination is high.

Corroborating many other research findings (Blunt \& Pylchyl, 2005; Ferrari, et al., 1997; Ferrari \& Scher, 2002), adolescents usually avoid difficult and disagreeable tasks that involve high demand of effort and for which they feel unprepared, and that could explain why procrastination increases with the number of course years failed (Blunt \& Pylchyl, 2005; Boice, 1993, 1995; Costa, 2007; Onwuegbuzie, 2000; Walker, 2004). 


\section{Final Conclusions}

The main goal of both studies was to increase our understanding and knowledge of academic procrastination in middle school. For this purpose, we explored the impact of socio-family and educational variables on academic procrastination behaviors. The results obtained show some relation among these variables, although the effect size is small (in both samples). Perhaps the most important fact is that the data obtained in Study 1 are replicated in Study 2, which reinforces the conclusions that can be derived.

The absence of statistically significant differences among some groups and, particularly, the weak effect size found in both studies, leads to the conclusion that this could be due to the fact that the effect of the variables studied (socio-family and educational) on academic procrastination could be mediated by other variables that are closer to the postponing behavior of tasks, (e.g., achievement expectations, self-efficacy, self-regulated learning strategies, as well as peers pressure, and the effect of groups and their rules on their members procrastination behaviors). The interesting "sibling effect" on procrastination found on this investigation could be due to and mediated by this group level variables. Future research on procrastination should take these variables into account in order to plan effective intervention strategies.

In other words, it would be important to design structural equation models to analyze the relations among different variables such as those relating to family (e.g., parents' expectations of their children's school success, profiles of parental involvement in children's school work, self-regulated learning experiences provided), personal (e.g., academic goals, causal attribution, self-efficacy, task value, self-regulated learning strategies), and social grounds (e.g., peer pressure, social future expectations, social interests).

In any case, in the absence of these data, the information provided by other researchers leads us to believe that in order to fight academic procrastination one could start by developing teaching strategies and by promoting behaviors rich in self-regulated learning skills within the family. It is essential to convince educators of the importance of promoting self-regulated learning processes, for example, by formulating goals, monitoring progress, time management, and placing emphasis on promoting successful experiences (Rosário, Mourão, Núñez, González-Pienda \& Solano, in press). Parents could help to prevent procrastination by developing study skills in their children that would allow them to avoid distractions (e.g., studying in comfortable, quiet settings; keeping their desk neat, fulfilling a work plan at home, turning off the TV and the cellular phone, etc.). These aspects could help to increase students' commitment to the tasks and to teach them to postpone gratification, essential dimensions in the promotion of will power competences and prevention of academic procrastination (Rosário et al., 2005). At the same time, achievement expectations can be induced in procrastinators, for example, by performing work plans that include intermediate goals, an adequate work setting, and assigning enough time to task performance (Rosário et al., 2007). These learning strategies, frequently used in cognitivebehavioral interventions, are specifically indicated for efficient time management, but they can have a significant impact on preventing academic procrastination, too (Schouwenburg, 2004).

The data provided in this work although modestly reinforce van Eerde (2003) pledge for further research focusing social influences on procrastination. They also suggest that the design of future intervention actions on this area targeting youths and educators should take into account those same social influences as an efficient strategy in helping to decrease procrastination and consequently promote academic success.

\section{References}

Aitken, M. (1982). A personality profile of the college student procrastinator. Unpublished Doctoral Dissertation. University of Pittsburgh.

Alexander E. S, \& Onwuegbuzie, A. J. (2007). Academic procrastination and the role of hope as a coping strategy. Personality and Individual Differences, 42, 1301-1310.

Blunt, A., \& Pylchyl, T. (2005). Project systems of procrastinators: A personal project-analytic and action control perspective. Personality and Individual Differences, 38, 1771-1780.

Boice, R. (1993). New faculty involvement of women and minorities. Research in Higher Education, 34, 291-341.

Boice, R. (1995). Developing teaching, then writing among new faculty. Research in Higher Education, 36, 415-456.

Brownlow, S., \& Reasinger, R. (2000). Putting off until tomorrow what is better done today: Academic procrastination as a function of motivation toward college work. Journal of Social Behaviour and Personality, 15, 15-34.

Burka, J.,, \& Yuen, L. (1983). Procrastination: Why you do it, what to do about it. Cambridge: Da Capo.

Costa, M. (2007). Procrastinação, auto-regulação e género. Tese de dissertação de mestrado não publicada. Braga, Portugal: IEP.

Delongis, A., Coyne, J. Dakof, G., Folkman, S., \& Lazarus, R. (1982). Relationship of daily hassles, uplifts and major life events on health status. Health Psychology, 1, 119-136.

Dewitte, S., \& Lens, W. (2000). Procrastinators lack a broad action perspective. European Journal of Personality, 14, 121-140.

Dewitte, S., \& Schouwenburg, H. (2002). Procrastination, temptation and incentives: The struggle between the present and the future in procrastination and the punctual. European Journal of Personality, 16, 469-489. 
Epstein, J. (2001). School, family, and community partnerships: Preparing educators and improving schools. Boulder, CO: Westview Press.

Ferrari, J.R., \& Díaz-Morales, J.F. (2007). Perceptions of selfconcept and self-presentation by procastinators: Further evidence. The Spanish Journal of Psychology, 10,( 1), 91-96.

Ferrari, J.R., \& Emmons, R. (1995). Methods of procrastination and their relation to self-control and self reinforcement. Journal of Social Behaviour and Personality, 10, 135-142.

Ferrari, J.R., Harriott, J., Evans, L., Lecik-Micnha, D., \& Wenger, J. (1997). Exploring the time preferences of procrastinators: Night or day, which is the one? European Journal of Personality, 11, 187-196.

Ferrari, J.R., Harriott, J., \& Zimmerman M. (1999). The social support networks of procrastinators: Friends or family in times of trouble? Personality and Individual Differences, 26, 321331.

Ferrari, J.R., Johnson, J., \& McCown, W. (1995). Procrastination and task avoidance: Theory, research and practice. New York: Plenum Press.

Ferrari, J.R., O'Callaghan, J., \& Newbegin, I. (2005). Prevalence of procrastination in the United States, United Kingdom, and Australia: Arousal and avoidance delays among adults. North American Journal of Psychology, 7, 1-6.

Ferrari, J.R., \& Olivetti, M. (1993). Perceptions of parental control and the development of indecision among late adolescent females. Adolescence, 28, 963-970.

Ferrari, J.R., \& Olivetti, M. (1994). Parental authority influences on the development of female dysfunctional procrastination. Journal of Research in Personality, 28, 87-100.

Ferrari, J.R., \& Scher, S. (2002). Toward an understanding of academic and nonacademic tasks procrastinated by students: The use of daily logs. Psychology in the Schools, 37, 359366.

Flett, G., Hewitt, P., \& Martin, T. (1995). Dimensions of perfectionism and procrastination. In J. R. Ferrari, J. Johnson, \& W. McCown, (Eds.), Procrastination and task avoidance: Theory, research and practice, (pp. 113-136). New York: Plenum Press.

Grolnick, W.,, \& Ryan, R. (1989). Parent styles associated with children's self-regulation and competence in school. Journal of Educational Psychology, 81, 143-194.

McCown, W., \& Johnson, J. (1989, April). Validation of an adult inventory of procrastination. Paper presented at the Society for Personality Assessment, New York.

Milgram, N., Sroloff, B., \& Rosenbaum, M. (1988). The procrastination in everyday life. Journal of Research in Personality, 22, 197-212.

Moon, S., \& Illingworth, A. (2005). Exploring the dynamic nature of procrastination: A latent growth curve analysis of academic procrastination. Personality and Individual Differences, 38, 297-309.

Onwuegbuzie, A. (2000). Academic procrastination and perfectionist tendencies among graduate students. Journal of Social Psychology and Personality, 15, 103-110.
Pylchyl, T., Coplan, R., \& Reide, P. (2002). Parenting and procrastination: Gender differences in the relations between procrastination, parenting style and self-worth in early adolescence. Personality and Individual Differences, 33, 271-285.

Rosário, P., Costa, M., Mourão, R., Núñez, J.C., González-Pienda, J.A. \& Valle, A. (in press). Procrastination, SRL and Math achievement. Academic Exchange Quarterly, 11, 4,

Rosário, P., Mourão, R., Núñez, J.C., González-Pienda, J.A., \& Solano, P. (2006). Escuela-familia: ¿es posible una relación recíproca y positiva? Papeles del Psicólogo, 27, 171-179.

Rosário, P., Mourão, R., Núñez, J.C., González-Pienda, J.A., \& Solano, P. (in press). Storytelling as a promoter of SelfRegulated Learning (SRL) throughout schooling. In A. Valle, J.C. Núñez, R.G. Cabanach, J.A. González-Pienda, \& S. Rodríguez (Eds.), Handbook of instructional resources and their applications in the classroom. NY: Nova Science.

Rosário, P., Mourão, R., Núñez, J. C., González-Pienda, J., \&Valle, A. (2006). SRL and EFL homework: gender and grade effects. Academic Exchange Quarterly, 10 (4), 135-140.

Rosário, P., Mourão, R., Núñez, J.C., González-Pienda, J.A., Solano, P., \& Valle, A. (2007). Eficacia de un programa instruccional para la mejora de procesos y estrategias de aprendizaje en la enseñanza superior. Psicothema, 19, 353-358.

Rosário, P., Mourão, R., Soares, S., Chaleta, E., Grácio, L., Núñez, J.C., \& González-Pienda, J. A. (2005). Trabalho de casa, tarefas escolares, auto-regulação e envolvimento parental. Psicologia em Estudo, 10, 343-351.

Rosário, P., Soares, S., Núñez, J.C., González-Pienda, J., \& Rúbio, M. (2004). Processos de auto-regulação da aprendizagem e realização escolar no ensino básico. Psicologia, Educação $e$ Cultura, 8, 141-157.

Rothblum, E., Solomon, L., \& Murakami, J. (1986). Affective, cognitive, and behavioural differences between high and low procrastinators. Journal of Counselling Psychology, 33, 387394.

Scher, S., \& Ferrari, J. (2000). The recall of completed and noncompleted tasks through daily $\operatorname{logs}$ to measure procrastination. Journal of Social Behaviour and Personality, $15,255-265$.

Scher, S., \& Osterman, N. (2002). Procrastination, conscientiousness, anxiety, and goals: Exploring the measurement and correlates of procrastination among school-aged children. Psychology in the Schools, 39, 385-398.

Schouwenburg, H. C. (2004). Trait procrastination in academic settings: An overview of students who engage in task delays. In H.C. Schouwenburg, C. Lay, T. Pylchyl, \& J. Ferrari, (Eds.), Counselling the procrastinator in academic settings (pp. 3-18). Washington: American Psychological Association.

Senécal, C., Koestner, R., \& Vallerand, R. (1995). Self-regulation and academic procrastination. The Journal of Social Psychology 135, 607-619.

Tice, D., \& Baumeister, R. (1997). Longitudinal study of procrastination, performance, stress, and health: The costs and benefits of dawdling. Psychological Science, 8, 454-458. 
Van Eerde, W. (2003). A meta-analytically derived nomological network of procrastination. Personality and Individual Differences, 35, 1401-1418.

Vohs, K.D, \& Baumeister, R.F. (2004). Understanding self-regulation: An introduction. In R.F. Baumeister \& K.D. Vohs (Eds.), Handbook of self-regulation (pp. 1-12). New York: Guilford Press.

Walker, L. (2004). Overcoming the patterns of powerlessness that lead to procrastination. In H. Schouwenburg, C. Lay, T. Pylchyl, $\&$ J. Ferrari, (Eds.), Counselling the procrastinator in academic settings (pp. 91-103). Washington: American Psychological Association.

Wolters, C.A. (2003). Understanding procrastination from a selfregulated learning perspective. Journal of Educational Psychology, 95, 179-187.

Received July 26, 2007 Revision received July 9, 2008 Accepted September 3, 2008 